\title{
Uma estética da deriva digital em Mar de Sophia, de Rui Torres
}

\author{
An Aesthetics of the Digital Leeway in Mar de Sophia, by Rui Torres
}

\author{
Vinicius CARVAlho Pereira \\ Universidade Federal de Mato Grosso
}

\begin{abstract}
27
Resumo: Na era da revolução digital, identidades e discursos se revelam cada vez mais impermanentes, em uma liquidez cara às telas de cristal dos aparatos tecnológicos que hoje medeiam parte significativa dos encontros entre leitores e textos literários. A fim de indagar os impactos da crescente liquefação cultural e discursiva no âmbito da lírica contemporânea, este artigo analisa a obra digital Mar de Sophia, de Rui Torres. Misturando recursos multimídia e procedimentos da lírica moderna, Torres relê poemas de Sophia de Mello Breyner Andresen, transpostos para o suporte digital e transcriados por recursos intertextuais de recorte, colagem e hibridação. Interessa-nos, sobretudo, compreender como elementos semióticos presentes nos textos da poetisa portuguesa são relidos em uma estética da deriva e da liquidez no softwarepoema de Rui Torres, o qual põe em deslize na tela os sintagmas de Andresen - flutuação do signo poético análoga à da navegação no cyberespaço.
\end{abstract}

Palavras-chave: Rui Torres; Poesia digital; Sophia de Mello Breyner Andresen; Deriva; Liquidez

\begin{abstract}
In the era of digital revolution, identities and discourses are growingly more impermanent, in a liquidity similar to that of the crystal screens of technological devices. Such devices mediate a significant share of the encounters between readers and literary texts nowadays. In order to question the impacts of the growing cultural and discursive liquefaction on contemporary poetry, we herein analyze the digital poem Mar de Sophia, by Rui Torres. By mixing multimedia resources and structures from modern poetry, Torres revisits poems by Sophia de Mello Breyner Andresen, which were transposed into the digital medium and transcreated by intertextual procedures of cutting, pasting and hybridization. We aim to understand how semiotic elements from texts by Andresen are revisited in an aesthetics of leeway and liquidity in the software-poem by Rui Torres. Such software sets Andresen's phrases adrift on the screen, so that the poetic sign floats the same way one surfs in the cyberspace.
\end{abstract}

Keywords: Rui Torres; Digital poetry; Sophia de Mello Breyner Andresen; Leeway; Liquidity

\section{Introdução}

Sophia de Mello Breyner Andresen, poetisa modernista portuguesa e primeira mulher do país a receber o mais importante galardão literário de nossa língua, o Prêmio Camões, em 1998, ficou célebre por sua estética ímpar na história da literatura portuguesa. Apesar de cultivar uma forma moderna, a autora adota um tom clássico no rigor da linguagem e uma atitude evocativa e solene diante do verbo, tal qual a do marinheiro que, frente ao mar, aceita sua condição de homem à deriva e entra em comunhão com o oceano que o lança entre as ondas.

A alegoria do mar não é aqui gratuita: óbvia que é sua presença na literatura de um país de marinheiros lusíadas, colônias ultramarinas e naus catrinetas, na obra de Sophia de M. B. Andresen o oceano comparece no plano da expressão e do conteúdo, com ondeantes versos e fluidas metáforas que falam, frequentemente, da praia e da navegação, como sugerem os títulos de algumas de suas obras, como Dia do Mar (1947), Coral (1950), Mar Novo (1958), Navegações (1983) e Ilhas (1989), sem contar seus textos narrativos e os voltados para a literatura infantil.

Hoje, porém, de outras formas a poesia portuguesa se apropria do mar como mote literário, transpondo-o das águas salgadas da praia do Tejo para o cyberespaço e seu oceano de bits e bytes, o qual, ainda que encaremos dia após dia, ainda tememos e desconhecemos, tal como 
aqueles marujos do célebre poema VI, de Sophia de M. B. Andresen:

\begin{abstract}
VI
Navegavam sem o mapa que faziam

(Atrás deixando conluios e conversas Intrigas surdas de bordéis e paços)

Os homens sábios tinham concluído

Que só podia haver o já sabido:

Para a frente era só o inavegável

Sob o clamor de um sol inabitável

Indecifrada escrita de outros astros

No silêncio das zonas nebulosas

Trémula a bússola tacteava espaços

Depois surgiram as costas luminosas

Silêncios e palmares frescor ardente

E o brilho do visível frente a frente

(ANDRESEN, 1991, p. 256)
\end{abstract}

Trazendo para nossos dias a cena descrita no poema acima, pode-se ver mais do que os protonautas lusitanos; na contemporaneidade, é um navegador como o do poema o leitor de cybertextualidades, infonauta que segue sem mapa em um oceano movediço de links e URLs, homepages, vídeos, áudios e textos escritos, construindo o percurso à medida que singra esse mar, ou navegando sem o mapa que então faz. Deixando o "já sabido" em busca do "inavegável" e do "inabitável", através de fluxos e correntes de dados digitais, tem ele também uma "trémula bússola [que] tacteava espaços" - o browser, ou navegador de Internet -, com que ruma para "costas luminosas" e se defronta com o "visível frente a frente". Em movimentos dialéticos entre o sabido e o insabido, o visível e o invisível, move-se por ondas informacionais aquele que Lúcia Santaella (2004) convencionou chamar de "leitor navegador previdente", que não tem mapa ou astrolábio, mas lê os sinais da tela (não mais dos astros) e traça, em meio às tormentas da rede, a sua rota.

Nesse novo e ainda desconhecido universo discursivo, tem-se lançado a poesia portuguesa, especialmente pelas mãos e pela voz de artistas como Rui Torres, professor e pesquisador da Universidade Fernando Pessoa, bem como membro de uma série de grupos de pesquisa e projetos internacionais na área de Estéticas Digitais. Tal autor vem se dedicando há quase duas décadas ao labor de crítico, pesquisador e poeta das literaturas digitais, tendo criado textos antológicos nessa vertente estética, com base em diferentes bancos de dados, algoritmos de combinatória e recursos multimodais. Rui Torres produziu obras em Flash que põem em releitura e fluxos de hibridação clássicos da literatura portuguesa, como 8 brincadeiras para Salette Tavares (2010), relendo textos da poetisa experimentalista;
Baladas eletrônicas para AlletSator (2009), com base em Álea e Vazio (1971), de E. M. de Melo e Castro, e Aforismos (1988), de Pedro Barbosa; e Húmus poema contínuo (2006), jogando com Húmus (1967), de Herberto Helder, e Húmus (1917), de Raul Brandão.

No bojo dos experimentalismos digitais do autor que retornam, por diferentes mares, às paragens canônicas da literatura portuguesa, este artigo analisa a obra Mar de Sophia (2004), de Rui Torres, releitura cyberpoética de textos de Sophia de Mello Breyner Andresen. Interessa aqui entender como elementos semióticos presentes nos textos da poetisa portuguesa são relidos em uma estética da deriva e da liquidez no software-poema de Rui Torres, o qual põe em deslize na tela os sintagmas de Andresen - flutuação do signo poético algo análoga à da navegação no cyberespaço. Para tanto, adotaremos também um percurso crítico como o do barco que baloiça no mar, ora pendendo para a obra Mar de Sophia, ora revisitando poemas da autora que estejam relacionados à obra digital aqui em análise.

\section{Mar de Sophia: navegando em águas outras}

Mar de Sophia (TORRES, 2004) é um cyberpoema produzido em meio aos experimentalismos literários digitais em Portugal, composto a partir de poemas de Sophia de Mello Breyner Andresen. Segundo a taxonomia adotada pelo Arquivo Digital da PO.EX $X^{1}$ (2016), referência nos estudos portugueses de cyberliteratura, Mar de Sophia é uma obra metatextual alógrafa, pois se enquadra entre "textos acerca de obras e práticas artísticas produzidos por agentes que não são autores das obras" (PO.EX, 2016, n.p.). Tal categorização segue princípios estabelecidos por Genette (2010), que cunhou o conceito de metatextualidade para se referir a relações transtextuais do tipo comentário, frequentemente englobando gêneros como o ensaio, a dissertação ou o prefácio. A partir daí, percebe-se o entendimento de Rui Torres diante de seu poema como crítica literária à obra da poetisa modernista portuguesa.

Mar de Sophia pode ser descrito grosso modo como um motor textual a que se sobrepõem camadas de som e animação visual de texto verbal, em uma arquitetônica baseada em recursos de Flash, Actionscript, XML, PHP e Python. Sua tela inicial (Figura 1) faz as vezes de ficha catalográfica, classificando a obra como um "poema hipermédia de Rui Torres a partir de textos de Sophia de Mello Breyner Andresen com a colaboração de Nuno F. Ferreira (programação), Nuno M. Cardoso (voz) e Luís Aly (som)".

Portal de literatura portuguesa experimental, sob curadoria de diversos pesquisadores, coordenados pelo próprio Rui Torres. 


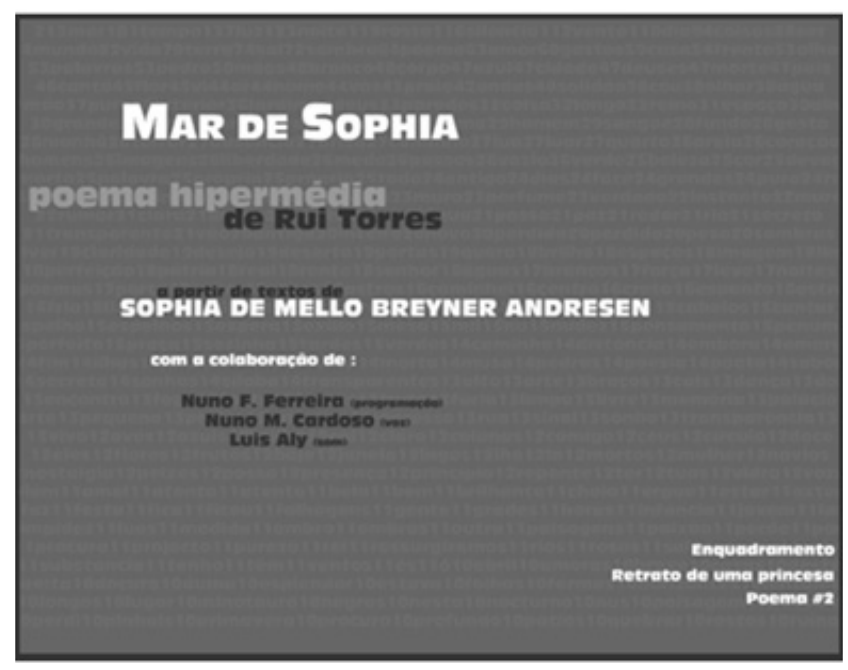

Figura 1. Tela inicial de Mar de Sophia (2004)

Tal descrição, estranha à maior parte das obras do gênero lírico, denota um primeiro dilema imposto pela cyberliteratura: tratando-se de obra de autoria coletiva (ou difusa, ou compartilhada, como queira o referencial teórico adotado), a quem se atribui a obra para fins de registro (em citações na academia, patentes na indústria, ou contratos de direitos autorais no mercado editorial)? Apenas ao autor do texto "original", que se tornou o mote da reescritura (no caso, Sophia de Mello Breyner Andresen)? Ou ao idealizador da releitura digital, Rui Torres? Incluem-se entre os (co?)autores os técnicos ou performers responsáveis por componentes multimodais, como imagens e som? Considera-se o programador, que escreve algoritmos que constituem o estrato formal da obra? E o leitor, que acaba co-criando na medida em que seus cliques desencadeiam mudanças na materialidade do texto? Questão de um mundo pós-autor, em que plágios, mixagens, samplings e contrabandos transtextuais são mais e mais abundantes, não se pretende neste artigo definir, para fins críticos, a autoria do texto. Simplesmente aqui se opta, para padronização das citações, por atribuir a autoria de Mar de Sophia a Rui Torres, (co?)criador do texto verbal, conforme sugere o adjunto adnominal "de Rui Torres" na tela da Figura 1. Note-se, no caso, que apenas junto a este nome próprio se empregou a preposição "de", indicativa de posse. A relação sintática (e também a noção de autoria) é mais frouxa quando a interface indica a partir dos textos de quem e com a colaboração de quem a obra foi feita, haja vista o arranjo dos sintagmas distanciando a preposição "de" dos nomes de Sophia e dos colaboradores.

Ainda na tela inicial, no canto inferior à direita, o leitor tem de deixar o porto e lançar-se ao mar, fazendo escolhas sobre seu percurso de leitura sem bem saber para onde vai, como o fazem os "Homens à beira-mar", do poema de Sophia de Mello Breyner Andresen:

\author{
Homens à beira-mar \\ Nada trazem consigo. As imagens \\ Que encontram, vão-se delas despedindo, \\ Nada trazem consigo, pois partiram \\ Sós e nus, desde sempre, e os seus caminhos \\ Levam só ao espaço como o vento. \\ Embalados no próprio movimento, \\ Como se andar calasse algum tormento, \\ O seu olhjar fixou-se para sempre \\ $\mathrm{Na}$ aparição sem fim dos horizontes. \\ (...) \\ (ANDRESEN, 1991)
}

O cyberleitor à beira-mar, que da orla da tela inicial do poema vê as possibilidades de navegação na obra através de links intitulados "Enquadramento", "Retrato de uma princesa" e "Poema\#2", precisa tomar uma decisão sobre qual caminho seguir, enquanto, ao fundo, um áudio em loop reproduz o som do vento e da quebrada das ondas na praia.

Replicando a estrutura da obra digital, procede-se aqui a uma subdivisão do artigo em três subseções a partir deste ponto, sendo cada uma delas referente aos trajetos por que passa o leitor caso clique em cada um dos links disponibilizados na tela inicial de Mar de Sophia.

\section{"Um por um para o mar passam os barcos / Passam em frente de promontórios e de terraços / Cortando as águas lisas como um chão" ${ }^{2}-$ ou ensaios de navegação conduzida}

Se, na interface de abertura de Mar de Sophia, o leitor clicar em "Enquadramento", é levado a águas mais tranquilas, sendo-lhe apresentado um conjunto de telas com signos metalinguísticos que o conduzem, de modo panorâmico e explicativo, através das regras de funcionamento da obra. À guisa de manual sobre o construto literário digital, a primeira tela da seção "Enquadramento" (Figura 2) apresenta um poema produzido por code-meshing, isto é, pela hibridização de línguas distintas em um mesmo discurso. Na região fronteiriça do Brasil com outros países latino-americanos, tal qual nos limites entre Portugal e Espanha, pratica-se code-meshing na medida em que os falantes passam a se valer do portunhol para fins comunicativos. Nesta tela de Mar de Sophia, porém, a hibridização se dá entre uma língua natural - o português - e uma linguagem de programação, no que se produz uma distribuição espacial de informações sobre a tela que lembra a disposição

\footnotetext{
2 Trecho do poema "Barcos" (ANDRESEN, 1991).
} 
de versos em uma página, típica do gênero lírico, mas também uma sucessão de linha de códigos, como em um programa de computador. Constrói-se, assim, um poema intitulado "//Mar de Sophia", em que as barras ganham um sentido especial, uma vez que designam, em linguagem de programação, um comentário sobre o código programado, e não um pedaço do código em si. Nesse caso, o caráter metalinguístico e explicativo da seção "Enquadramento", acerca do funcionamento da obra Mar de Sophia, vem reduplicado no poema que abre essa seção, o qual se apresenta desde o título como um comentário sobre a obra.

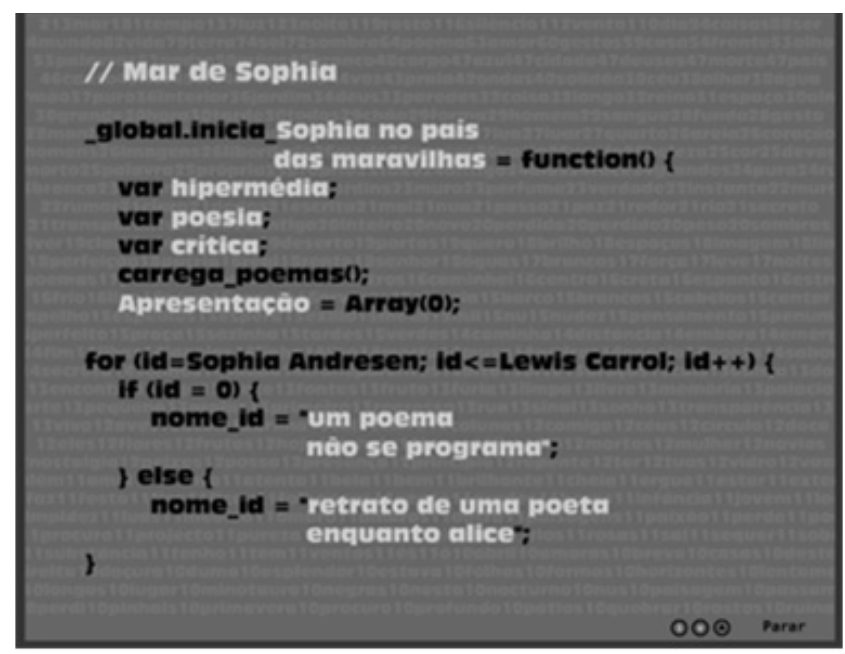

Figura 2. Primeira tela da seção "Enquadramento", de Mar de Sophia (2004)

Em tradução bastante frouxa da mensagem postulada por essa textualidade híbrida entre verso e algoritmo, no que parece ser a primeira "estrofe" apresenta-se uma função (Sophia no país das maravilhas), cujas variáveis são hipermédia, poesia e crítica. Note-se aí uma nova corrente intertextual que se soma ao mar por que navega o leitor: ao adentrar o insabido do poema digital, descortina-se-lhe um mundo de fragmentos poéticos da obra de Sophia de Mello Breyner Andresen imiscuídos a termos e imagens da obra Alice no País das Maravilhas, como nos explica a tese de doutorado de Bonacho (2013, p.146), a qual contou com o apoio do próprio Rui Torres em sua empreitada:

o facto de o autor ter adicionado ao léxico de Sophia, no "Retrato de uma Princesa, uma amostra do léxico retirado de Alice no País da Maravilhas de Lewis Carrol (...) parece sugerir uma ironia criativa que liga esta poesia electrónica às associações inesperadas $\mathrm{e}$ surreais das aventuras de Alice.
Não são raras as análises acadêmicas sobre a intertextualidade entre a obra da poetisa portuguesa e o mais famoso livro de Lewis Carroll, especialmente no que tange ao caráter fantástico das paisagens insulares com que se defrontam as personagens de Sophia, geralmente após uma travessia cheia de percalços como a que Alice faz pelo País das Maravilhas. A segunda metade do poema "Homens à beira-mar" dá-nos a ver um pouco da ambiência carrolliana em que os marujos se defrontam, ainda que em sonhos à beira-mar, com o exótico mundo de "aves estrangeiras", areia sobre que deitam o traço "passo a passo", sem jardim ou olhar que os prenda.

(...)

Como o animal que sente ao longe as fontes,

Tudo neles se cala para auscultar

O coração crescente da distância,

E longínqua lhes é a própria ânsia.

É-lhes longínquo o sol quando os consome,

É-lhes longínqua noite e a sua fome.

É-lhes longínquo o próprio corpo e o traço,

Que deixam pela areia, passo a passo.

Porque o calor do sol não os consome,

Porque o frio da noite não os gela,

E nem sequer lhes dói a própria fome,

E é-lhes estranho até o próprio rasto.

Nenhum jardim, nenhum olhar os prende,

Intactos nas paisagens onde chegam

Só encontram o longe que se afasta,

As aves estrangeiras que os traspassam,

E o seu corpo é só um nó de frio

Em busca de mais mar e mais vazio.

(ANDRESEN, 1991)

Como esses homens à beira-mar, "em busca de mais mar e mais vazio", temos no intertexto de Alice no País das Maravilhas uma cena bastante semelhante. Nesta, encontra-se a protagonista também entre aves estrangeiras - um pato, um dodô, um papagaio e uma águia - correndo, em uma ilha, para secar-se após quase sofrer um afogamento em meio às suas lágrimas - surrealista imagem como a de marinheiros que "só encontram o longe que se afasta". E, se de lágrimas e mar são as águas salgadas que rodeiam os marujos de Sophia e a Alice de Carroll, tem-se aí um retorno a uma das metáforas estruturantes da literatura portuguesa, resumida com maestria nos versos pessoanos: "Ó mar salgado, quanto do teu sal/São lágrimas de Portugal!" (PESSOA, 1996).

Nesse reencontro entre a tradição e a novidade, o cânone do mundo impresso e a releitura digital, o híbrido entre poema e programa de computador, revelado na Figura 2, joga ainda com outros fluxos intertextuais, 
em uma modernidade líquida que o aquático mar e o oceano digital bem representam. Assim, no que parecem ser os últimos dois tercetos do metalinguístico "//Mar de Sophia", estabelece-se um laço condicional, estrutura típica de algoritmos construída a partir da relação lógica "se X então Y". Nesse caso, o que o código sugere acerca de seu funcionamento é uma bifurcação na rota do leitor navegante, visto que a máquina opera a partir de uma escolha, a depender do valor das variáveis envolvidas: ou Mar de Sophia trabalha considerando que "um poema não se programa", ou considerando "o retrato de uma poeta enquanto Alice".

O sintagma "retrato de uma poeta enquanto Alice", além de explicitar a intertextualidade acima mencionada com o romance de Lewis Carroll, joga ainda com a estrutura sintática do título de $A$ Portrait of the Artist as a Young Man, de James Joyce, às vezes traduzido para o português como Retrato do artista quando jovem, às vezes traduzido como Retrato do artista enquanto jovem. $\mathrm{Tal}$ romance, um dos inauguradores de uma estética da deriva na narração em prosa do pós-modernismo inglês, investe nos descaminhos por que o fluxo de consciência das personagens e o discurso indireto livre conduzem o leitor, muitas vezes perdido como os navegantes dos poemas de Sophia de M. B. Andresen ou os cyberleitores de Mar de Sophia. Ademais, o sintagma "retrato de" remete também ao poema "Retrato de uma princesa desconhecida", da poetisa portuguesa, o qual serve como matriz para os experimentos poéticos da seção "Retrato de uma princesa", como se verá mais à frente neste artigo.

Também a opção "um poema não se programa", estabelecida como um dos percursos do laço condicional do poema "//Mar de Sophia", põe-nos mais uma vez à deriva entre textos da poetisa portuguesa e suas releituras no universo digital, agora remetendo ao poema "Liberdade":

Liberdade
O poema é
A liberdade
Um poema não se programa
Porém a disciplina
- Sílaba por sílaba -
O acompanha
Sílaba por sílaba
O poema emerge
- Como se os deuses o dessem
O fazemos

(ANDRESEN, 1977)

O texto acima, de caráter eminentemente metapoético, define o poema como produto não do engenho, do esforço ou do planejamento consciente; revisita, em vez disso, o ideário romântico do poema como exercício de liberdade e/ou dádiva de entidades suprassensíveis, sejam elas as musas, os deuses ou a própria Poesia personificada. Nesse sentido, um poema não se programa: recebe-se o poema.

No entanto, o verso "um poema não se programa" ganha novas significações quando transposto para uma obra digital e, mais ainda, para um metapoema que descreve, logo no início da obra, como esta opera, hibridizando linguagens de programação e a língua portuguesa para fazer releituras da obra de Sophia de Mello Breyner Andresen. Nesse caso, a ideia de que um poema não se programa se retorce sobre si mesma e dá a ver Mar de Sophia como um poema digital que é fruto de programação computacional e, portanto, gera novos textos ao recombinar trechos da poética de Andresen. Paradoxalmente, a máquina-poema - programada pela equipe de Rui Torres - produz poemas não programáticos, isto é, não previsíveis ou planejados, uma vez que os algoritmos que recombinam fragmentos das obras de Sophia dão origem a um número tão alto de produtos poéticos possíveis que a vida humana não permite, por ser tão curta, ler. A programada obra digital de Rui Torres produz, então, poemas que não se programam, em um desses paradoxos em que Alice tanto se envolvera quando no País das Maravilhas.

Rápida que é a cadência das ondas do mar, também o é o ritmo em que se sucedem as telas da seção "Enquadramento", de maneira que a detida análise acima empreendida foi apenas possível depois de um clique no botão "Parar", disponível no canto inferior à direita. Eis-nos, afinal, diante da velocidade e da aceleração caras à modernidade líquida e à cyberliteratura, em que à permanência do papel opõe-se a efemeridade da tela digital de cristal líquido, sobre a qual deslizam as interfaces de Mar de Sophia.

Nas telas seguintes da seção "Enquadramento", alternam-se explicações técnico-estéticas de Rui Torres sobre o funcionamento e a elaboração da obra e capturas de tela de diferentes camadas de seu texto: a lâmina d'água da interface que o leitor verá ao navegar na seção "Retrato de uma princesa" (Figura 3) e as águas mais profundas que o leitor não vê, mas nas cujas correntezas o autor enfrentara, como na camada de programação da obra (Figura 4) e na de animação e mobilização de hipermídias (Figura 5).

A esse respeito, cabe lembrar que, por mais que se distanciem do que se convencionou chamar literatura na história cultural do Ocidente, todas essas camadas revelam diferentes níveis de uma escritura, cuja interoperação garante os efeitos estéticos apresentados ao leitor na interface. Sendo, pois, o computador uma máquina que funciona regida por uma escrita - a dos códigos 
algorítmicos - trata-se sempre de máquina semiótica (BARBOSA, 2001), em que pode a poesia vir à tona a partir das grafias mais inusitadas, como as das Figuras 4 e 5, conforme ficará mais claro na próxima subseção do presente artigo.
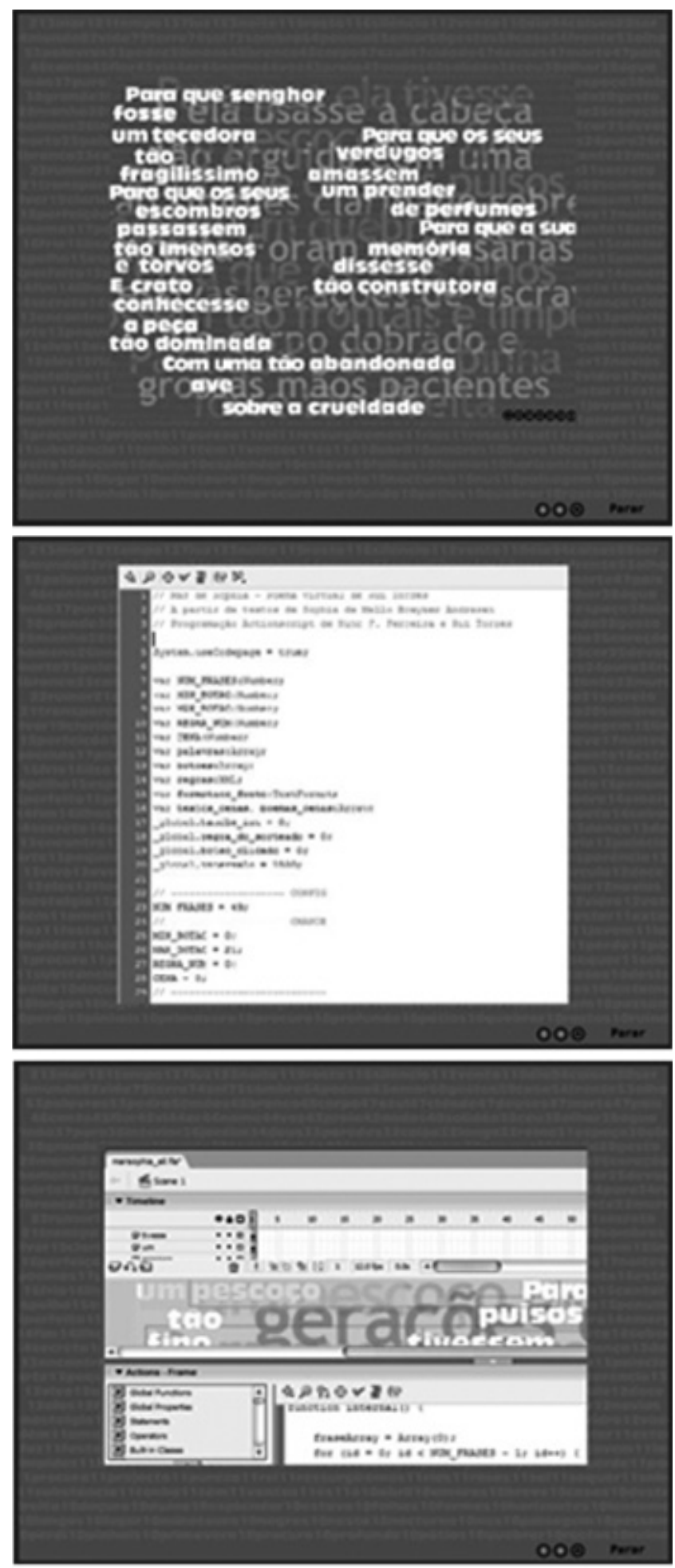

Figuras 3-4-5. Telas subsequentes da seção "Enquadramento", de Mar de Sophia (2004)
"E os poemas serão o próprio ar / - Canto de ser inteiro e reunido - / Tudo será tão próximo do mar / Como o primeiro dia conhecido" 3 - ou o estranhamento do óbvio

Se, na interface de abertura de Mar de Sophia, o leitor clicar em "Retrato de uma princesa", é direcionado para águas textuais ao mesmo tempo conhecidas e estranhas. A tela que se lhe abre diante dos olhos é o núcleo da obra de Rui Torres, apresentando, de fato, sua releitura digital do poema "Retrato de uma princesa desconhecida", um dos mais célebres textos de Sophia de Mello Breyner Andresen:

\section{Retrato de uma princesa desconhecida \\ Para que ela tivesse um pescoço tão fino \\ Para que os seus pulsos tivessem um quebrar de caule Para que os seus olhos fossem tão frontais e limpos \\ Para que a sua espinha fosse tão direita \\ E ela usasse a cabeça tão erguida \\ Com uma tão simples claridade sobre a testa \\ Foram necessárias sucessivas gerações de escravos \\ De corpo dobrado e grossas mãos pacientes}

Servindo sucessivas gerações de príncipes

Ainda um pouco toscos e grosseiros

Ávidos cruéis e fraudulentos

Foi um imenso desperdiçar de gente

Para que ela fosse aquela perfeição

Solitária exilada sem destino

(ANDRESEN, 2004, p. 73)

Na obra de Rui Torres, porém, não é nesse formato conhecido que o poema é revisitado. Em vez disso, a releitura proposta na seção "Retrato de uma princesa" apresenta um texto fragmentado e estratificado em múltiplas camadas e dimensões (Figura 6).

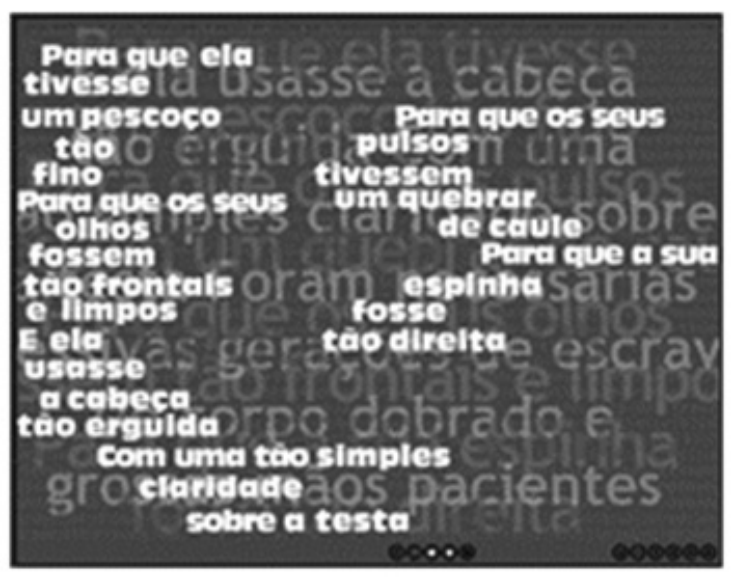

Figura 6. Primeira tela da seção "Retrato de uma princesa", de Mar de Sophia (2004)

\footnotetext{
Trecho do poema "Ali, então" (ANDRESEN, 2004)
} 
A fragmentação dos versos de Sophia em lexias dispostas em versos curtos e espalhados na tela replica, para o plano da expressão, a abordagem metonímica que o poema original faz da princesa, a qual não é apreendida como um todo, mas sim como uma sequência de pescoço, pulsos, olhos, espinha e cabeça. Como que à deriva, as palavras dos versos se espalham pela tela, lançando o leitor diante de uma versão desconhecida de um poema conhecido, experiência estética por vezes aflitiva, porque desconstrói o sabido do que se vê. A esse respeito, note-se que, se o poema de Sophia de Mello Breyner Andresen se chama "Retrato de uma princesa desconhecida", sua releitura se encontra em Mar de Sophia sob o link "Retrato de uma princesa", sintagma que esconde (porque soçobra?) o adjetivo "desconhecida" e, portanto, explicita o jogo entre águas familiares e inexploradas por que navega o leitor.

Simultaneamente ao que se vê, por semiose multimodal Mar de Sophia se dá a ouvir: junto com os versos que a tela revela a partir do link "Retrato de uma princesa", ouve-se uma leitura do poema "Retrato de uma princesa desconhecida", entrecortada por ruídos de toda sorte, aleatoriamente selecionados e reproduzidos a partir de um banco de dados. Entre esses sons que, como numa tormenta, desorientam o navegador, o leitor aqui escuta barulhos de vento, ondas quebrando contra a praia, sopros, chiados, bater de relógios, sons de instrumentos musicais e ruídos eletrônicos não identificáveis.

Mar que é, a releitura de Rui Torres não é estática nem no plano sonoro, nem no visual. Em alguns segundos, a materialidade textual na tela vai sofrendo alterações automaticamente, por meio de substituição de palavras do poema, como se nota na sequência das Figuras 7 e 8 .

$\mathrm{Na}$ passagem da tela da Figura 6 para a da Figura 7, vê-se que foram substituídos os seguintes termos: "fossem" por "germinassem", "simples" por "negra", "testa" por "onda", "tivessem" por "quisessem" e "direita" por "distante. Já da Figura 7 para a 8, trocou-se "pescoço" por "retrato" e "cabeça" por "caverna". Sendo classificado como um motor textual, este poema de Mar de Sophia consiste em uma matriz sintática extraída do "Retrato de uma princesa desconhecida", cujos termos lexicais (substantivos, adjetivos, verbos e alguns advérbios) são constantemente substituídos, por obra de programação. A cada uma dessas substituições, o software apaga uma palavra do poema e preenche seu espaço por outro vocábulo, aleatoriamente selecionado a partir de toda a obra poética de Sophia de Mello Breyner, respeitando-se, porém, as restrições gramaticais da língua portuguesa. Assim, verbos são apenas substituídos por verbos (e sempre flexionados para concordar com o sujeito), adjetivos são apenas substituídos por adjetivos (e também flexionados para concordar com os substantivos que caracterizam) etc.
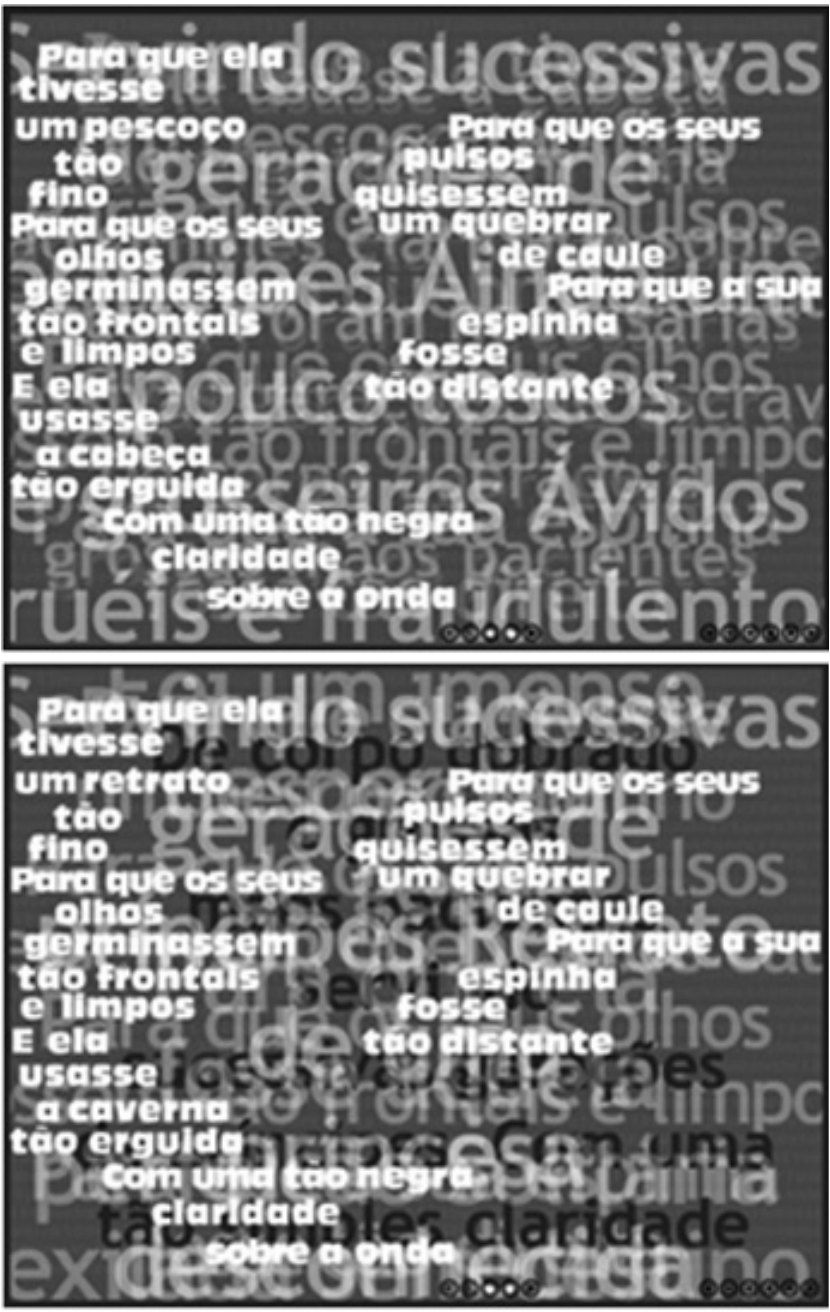

Figuras 7-8. Telas subsequentes da seção "Retrato de uma princesa", de Mar de Sophia (2004)

Diante desse jogo de permutas, em que Mar de Sophia inflaciona o eixo do paradigma trazendo à tela todos os textos da poetisa portuguesa, a partir de rearranjos de um único poema seu, pode o leitor deixar-se conduzir pelas ondas e assistir ao mistério da criação - "Sílaba por sílaba/O poema emerge" (ANDRESEN, 1977) - ou interferir ativamente no transcurso do texto - Como se os deuses o dessem/ O fazemos" (ANDRESEN, 1977).

Caso opte por deixar o motor textual atuar livremente, como barco que vai ao sabor da maré, pode o leitor defrontar-se com belos sintagmas, produzidos aleatoriamente pela máquina, como "e ela/ usasse/a cabeça/tão erguida/com uma tão negra/ claridade/sobre a onda" (Figura 7). Curioso é pensar que, por mais randômica que seja essa construção, ganha ela aqui sentido, se entendermos que o leitor que navega na obra tem também de erguer sua cabeça acima da onda que embaralha e transforma os versos de Sophia, lançando-os num chiaroscuro - tão negra claridade - entre o conhecido e o desconhecido da significação. 
Por outro lado, se prefere assumir o leme e definir o seu percurso naval, tem o leitor à sua disposição alguns comandos na forma de botões na parte inferior da tela. Entre as opções para que o leitor interaja mais ativamente com o poema, pode ele acelerar ou desacelerar a cadência com que as palavras do poema são alteradas; "animar o poema", isto é, colocar em deslizamento os versos que aparecem na tela; ou passar seja para a próxima tela, seja para uma anterior. Nesse sentido, vale dizer que há basicamente três telas nessa seção de Mar de Sophia, sendo cada uma delas uma matriz diferente (a partir de cada uma das estrofes de "Retrato de uma princesa desconhecida") para a recombinação de palavras que o software perpetra.

Caso deseje ir ainda mais longe em sua navegação, pode o leitor clicar no botão que altera o banco de dados de que se vale a máquina para substituição de palavras no poema. Assim, embora a opção "padrão" seja a permuta por termos extraídos de outros textos de Sophia de Mello Breyner Andresen, o leitor, ao clicar em um dos botões na parte inferior da tela, troca a fonte de palavras em potência onde bebe o poema. Passa, então, a máquina a substituir os termos lexicais da matriz por palavras de mesma classe gramatical extraídas do romance Alice no País das Maravilhas, como o poema "//Mar de Sophia", da seção "Enquadramento", já anunciara. Após alguns segundos, tal rota de leitura pode desembocar neste porto (Figura 9), entre vários outros possíveis:

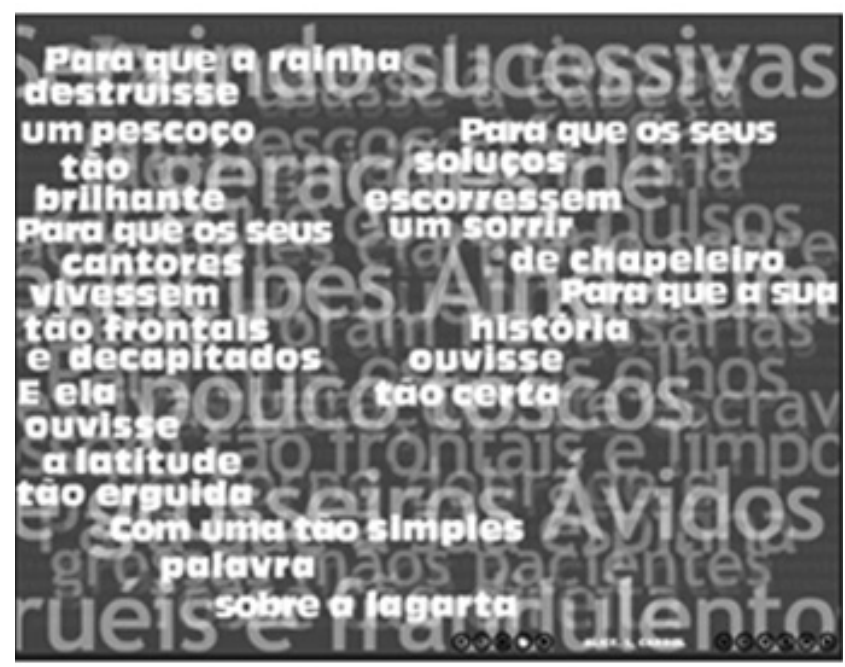

Figura 9. Tela de poema recombinado na seção "Retrato de uma princesa", de Mar de Sophia (2004

Já bem menos reconhecível como desdobramento da estrofe de Sophia de Mello Breyner Andresen, este fragmento guarda a estrutura sintática de parataxe entre as imagens iniciadas com "para que", as quais sugerem uma noção de finalidade, no poema original, indicando uma possível (e fútil) justificativa para a exploração do trabalho escravo. Na releitura, todavia, essas justificativas se tornam lábeis e moventes, haja vista a deriva das palavras que as compõem, o que põe em xeque o discurso teleológico da colonização.

Além disso, sendo da ordem do absurdo e do nonsense as imagens que se criam em um poema aleatoriamente composto por uma máquina, como, por exemplo, na oração "e ela ouvisse a latitude tão erguida com uma simples palavra sobre a lagarta", ganha novos sentidos a intertextualidade com a fantástica obra Alice no País das Maravilhas e suas personagens surreais que surgem no poema, como a Rainha de Copas, a Lagarta e o Chapeleiro Maluco. A esse respeito, interessante é notar que, assim como é por fragmentação e permutas que o software relê a poesia de Sophia de Mello Breyner Andresen, também é de um corte (de cabeça) que a Rainha de Copas vive ameaçando Alice e seus soldados-baralho, os quais permutam as cores das rosas de seu jardim, pintando de carmesim as flores brancas. Entre o crime e a punição, a permuta e o corte, é trapaceiro também o Mar de Sophia, que joga com as regras da língua e os algoritmos da máquina para construir imagens híbridas com o romance Alice no País das Maravilhas, cantando o corte do pescoço da princesa desconhecida: "para que a rainha/destruísse/um pescoço/tão brilhante/para que os seus/cantores/vivessem/tão frontais/e decapitados".

Em paralelo às mudanças no poema, também o plano de fundo de Mar de Sophia mantém-se em liquidez incontrolável. Em todas as telas do sistema, o background sugere visualmente uma superposição de textos em camadas, em clara alusão aos diferentes níveis da textualidade que uma obra dessa natureza impõe: o texto que o leitor vê na tela; o poema de Sophia de Mello Breyner Andresen que serve como matriz (ou molde) para a experiência estética; os outros textos da poetisa e Alice no País das Maravilhas, a que são surrupiados termos léxicos para as substituições no molde do "Retrato de uma princesa desconhecida"; a programação do software; o banco de dados etc. Metaforizando essa arquitetura em camadas, o plano de fundo de todas as telas da obra mostra fragmentos de textos de Sophia redigidos em cores e fontes distintas, as quais também vão cambiando conforme a leitura, como as diferentes cores que o mar assume de acordo com a profundidade da região onde se navega.

\section{"Vinha de um mundo/Sonoro, nítido e denso./ E agora o mar o guarda no seu fundo/Silencioso e suspenso" ${ }^{4}$ - ou os destroços do navio}

A terceira e última seção do Mar de Sophia por onde pode o leitor navegar é acessada na página inicial da obra por meio do link "Poema \#2". Aqui a experiência

\footnotetext{
4 Trecho do poema "Navio Naufragado" (ANDRESEN, 1991).
} 
estética consiste em um compósito poético formado aleatoriamente por versos de distintos textos de Sophia de Mello Breyner Andresen, os quais são dispostos um acima do outro e centralizados na tela, criando a impressão de um encadeamento em estrofes, mas progressivamente substituídos por outros, conforme se pode ver comparando as Figuras 10 e 11.

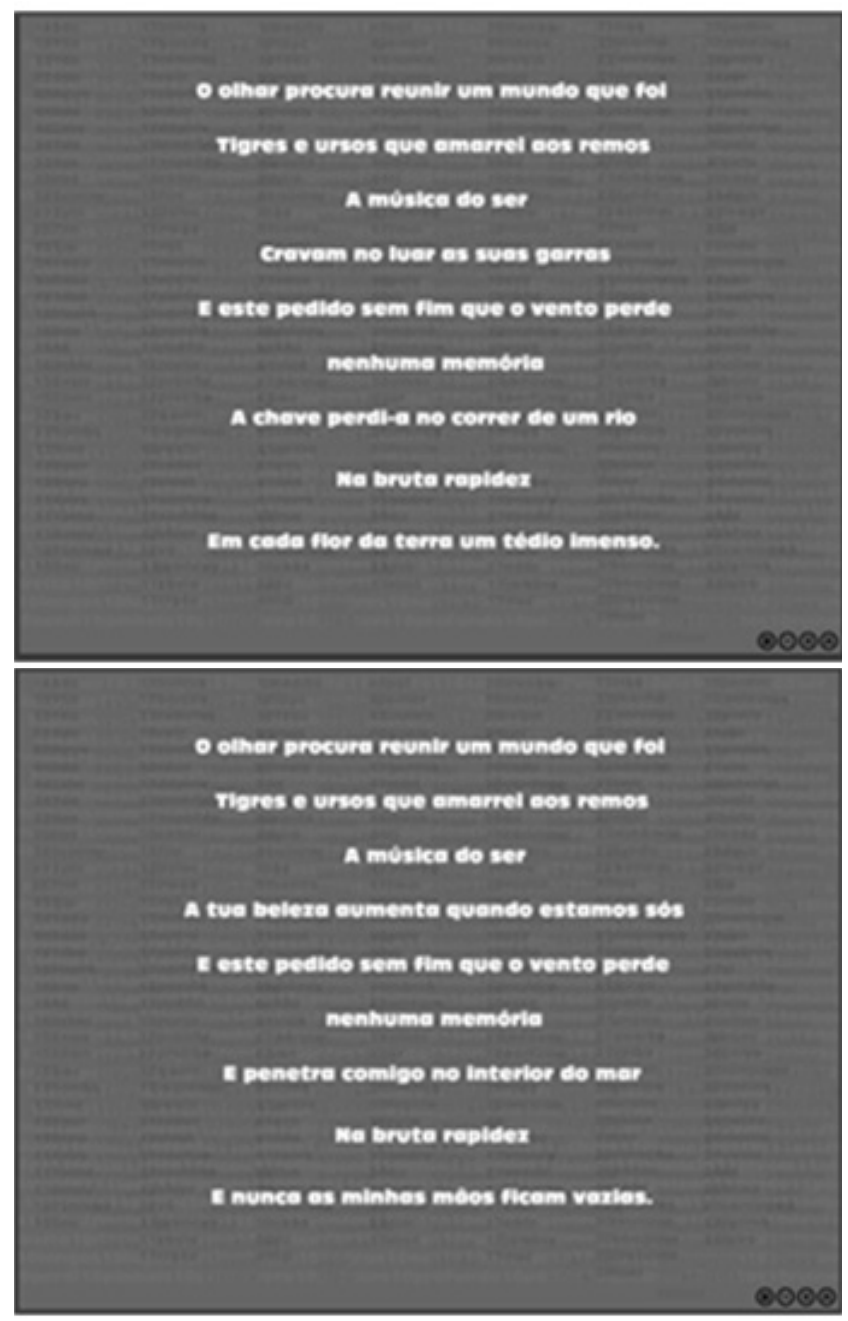

Figuras 10-11. Telas da seção "Poema \#2", de Mar de Sophia (2004)

Os versos que se encaixam para formar esses poemas são algumas das opções possíveis em um vastíssimo banco de dados, alimentado com versos de toda a obra de Sophia de Mello Breyner Andresen. No entanto, diferente do que havia na seção "Retrato de uma princesa", não há em "Poema \#2" um molde preenchido por palavras registradas no sistema. Em vez disso, as unidades de combinatória com que opera o algoritmo são os versos da poetisa, aleatoriamente justapostos para formar novos poemas. Nesse sentido, é interessante que o título da seção, "Poema \#2", é indiciário do seu conteúdo, uma vez que: a. esta é a segunda operação poética que a máquina enseja (a primeira é a que se viu na seção "Retrato de uma princesa"); e b. os versos randomicamente extraídos de seus poemas e lançados na tela em junção a outros que vêm de alhures dão sempre origem a um poema segundo, formado por partes alienadas de si mesmas e deslocadas para esse estranho lugar onde se encontram.

Defrontado com uma experiência de leitura como essa, o leitor que navegava pela obra como que naufraga, em meio à tormenta de correntes textuais tão díspares que confluem para um mesmo poema, combinado pela máquina. Afundado seu barco, é de destroços de outras naus poéticas que se constroem as imagens combinadas por "Poema \#2", tal qual a paisagem subaquática que se vê no poema "Navio naufragado", de Sophia de Mello Breyner Andresen.

\author{
Navio naufragado \\ Vinha dum mundo \\ Sonoro, nítido e denso. \\ E agora o mar o guarda no seu fundo \\ Silencioso e suspenso. \\ É um esqueleto branco o capitão, \\ Branco como as areias, \\ Tem duas conchas na mão \\ Tem algas em vez de veias \\ E uma medusa em vez de coração. \\ Em seu redor as grutas de mil cores \\ Tomam formas incertas quase ausentes \\ E a cor das águas toma a cor das flores \\ E os animais são mudos, transparentes. \\ E os corpos espalhados nas areias \\ Tremem à passagem das sereias, \\ As sereias leves de cabelos roxos \\ Que têm olhos vagos e ausentes \\ E verdes como os olhos dos videntes. \\ (ANDRESEN, 1991)
}

Tal qual a paisagem do navio naufragado, que se compõe da reunião de elementos dispersos e díspares, como o esqueleto do capitão, as conchas, as algas e a medusa, também os textos do "Poema \#2" são fruto de colagem e articulação de destroços, diante dos quais o leitor se põe como as sereias, "que têm olhos vagos e ausentes/E verdes como os olhos dos videntes". Com estes olhos de ver em ausência, admira-se o leitor com o poema que tem diante dos olhos, fruto da reunião de outros textos, e também com os que ali só existem em ausência, metonimizados na rede intertextual através do único verso com que comparecem no compósito de fragmentos.

A Figura 10, por exemplo, revela a captação da tela em que, por um momento, antes de que novas permutas fossem feitas pela máquina, formou-se o seguinte texto, que apresentamos em tabela de duas colunas a fim de explicitar a origem de cada um de seus versos: 
Tabela 1. Versos de Sophia recombinados por Mar de Sophia (2004)

\begin{tabular}{lll}
\hline & Verso no poema recombinado pelo software (Figura 11) & Poema de Sophia de que o verso foi retirado \\
1 & O olhar procura reunir um mundo que foi & "O sol o muro o mar" \\
2 & Tigres e ursos que amarrei aos remos & "Pirata" \\
3 & A música do ser & "Bach Segovia Guitarra" \\
4 & Cravam no luar as suas garras & "Os pássaros" \\
5 & E este pedido sem fim que o vento perde & "Árvores" \\
6 & nenhuma memória & "De um amor morto" \\
7 & A chave perdi-a no correr de um rio & "Fechei à chave" \\
8 & Na bruta rapidez & "Ilha do príncipe" \\
9 & Em cada flor da terra um tédio imenso & "Pra minha imperfeição" \\
\hline
\end{tabular}

Uma leitura do poema no eixo sintagmático, isto é, no eixo dos versos que estão presentes em sua materialidade textual, revela uma colagem de imagens díspares, a que é difícil atribuir uma coerência discursiva mínima para interpretação: reúnem-se aí olhares, feras, música, rio e flor, em frouxas articulações sintáticas, como na não concordância verbal que se estabelece entre os versos $3 \mathrm{e}$ 4. Sendo os versos no "Poema \#2" sempre recombinados aleatoriamente, a progressão temática, ou mesmo a continuidade sintática, por meio do enjambement, só se dá ao acaso, termo estranho à academia ou à ciência, mas não tão alheio da realidade dos marinheiros que contam muitas vezes só com a própria sorte. Nesse sentido, é interessante notar que, embora se choquem muitos dos versos desse poema recombinado, os últimos três formam uma estrutura sintática perfeita e uma imagem interpretável no contexto da leitura que aqui se propõe: "A chave perdi-a no correr de um rio/Na bruta rapidez/ Em cada flor da terra um tédio imenso". Se a ideia de chave pressupõe o fechamento de uma passagem, é de hermetismo também que fala este poema: fechada a porta de uma leitura estável, para um poema de Sophia fixo na página, como o conhecemos, só há aqui sintagmas que correm "na bruta rapidez" da tela, levando consigo toda possibilidade de exegese fixa, ou de tédio imenso, como as imóveis flores da terra. A lírica de "Poema \#2" é de água, e não terra, é de rapidez e efemeridade, em que "O olhar procura reunir um mundo que foi", criando sentidos a partir dos destroços de poemas afundados, como no já aqui mencionado texto "Navio naufragado".

Tal leitura metapoética do texto randomicamente produzido pela máquina é ratificada se navegarmos pelas rotas transtextuais a que essa poética convida. $\mathrm{O}$ verso "A chave perdi-a no correr de um rio", por exemplo, foi retirado do breve poema "Fechei à chave" (ANDRESEN, 1991), em que se lê um quarteto acerca da labilidade das imagens poéticas: "Fechei à chave todos os meus cavalos/A chave perdi-a no correr de um rio/Que me levou para o mar de longas crinas/Onde o caos recomeça - incorruptível". Uma vez que o rio poético leva aqui a um mar onde o caos desemboca e renasce cíclico, assistimos no funcionamento de "Poema \#2" à realização dessa promessa, na forma de um sistema em que desembocam poemas que devêm, fragmentária e ininterruptamente, torvelinho lírico.

Tais destroços líricos, lembranças dos poemas que naufragaram e se dissolveram em versos para registro no banco de dados, também se deixam a ver no poema "O sol o muro o mar" (1991), de onde foi extraído o verso "O olhar procura reunir um mundo que foi", ao qual se segue, no original, a linha "destroçado pelas fúrias". Por ação das Fúrias, encarnação da vingança na Mitologia Grega, é destruído o mundo que descreve o poema "O sol o muro o mar", que mais à frente define o papel do poema e do poeta ante tamanha exícia:

Essa é a missão do poeta: trazer para a luz e para o exterior o medo.

Muros sem nenhum rosto morados por densas ausências.

Não o homem mas os sinais do homem, a sua arte, os seus hábitos, o seu violento azul, o espesso amarelo, a veemência da cal.

(ANDRESEN, 1991, p.318-319)

Diante dos escombros, cabe ao poeta trazer de volta não o homem, mas somente metonímias suas, como os sinais, a arte, os hábitos, o violento azul, o espesso amarelo e a veemência da cal. Do mesmo modo, "Poema \#2" traz à superfície não os textos de Sophia de Mello Breyner Andresen, mas apenas traços seus, que evocam, coberta pela lâmina d'água do sistema, um informe porque líquido - volume poemático disperso no banco de dados, como "a música do ser" a que alude a colagem poética feita pelo software.

Dessa dispersão, emergem e submergem continuamente outros versos no texto maquínico, trazidos como 
que "Dos abismos da noite lenta e quieta/Palavras estridentes e cruéis", conforme os dois versos que antecedem a linha "cravam no luar as suas garras" no poema “Os pássaros" (1991), de onde a máquina o pilhara:

\section{Os pássaros}

Ouve que estranhos pássaros de noite

Tenho defronte da janela:

Pássaros de gritos sobreagudos e selvagens

O peito cor de aurora, o bico roxo,

Falam-se de noite, trazem

Dos abismos da noite lenta e quieta

Palavras estridentes e cruéis.

Cravam no luar as suas garras

E a respiração do terror desce

Das suas asas pesadas.

(ANDRESEN, 1991)

É só ouvindo estes pássaros que sobrevoam o mar - presságio de que há terra firme próxima, como bem se sabe de tantos relatos dos marinheiros portugueses que os leitores podem aceitar a deriva e a desorientação trazida pelas incertas ondas textuais do Mar de Sophia. Diante da textualidade que foge aos olhos e não se detém sequer para que a leitura se complete, pois um novo termo ou verso sempre surge nos poemas deste sistema, os leitores também "cravam no luar as suas garras", tentando firmar um apoio nos movediços sintagmas que se veem desaparecer enquanto "a respiração do terror desce", e se aguarda que a tempestade os leve a um porto seguro.

\section{Considerações finais}

O presente trabalho analisou como uma poética da liquidez e da deriva, cara às manifestações literárias contemporâneas na Internet, ressignificou a lira de Sophia de Mello Breyner Andresen por meio da releitura proposta por Mar de Sophia. Viu-se aqui que a temática do mar e seus caprichos, cara à poetisa portuguesa, é transposta para os planos do conteúdo e da expressão do sistema engenhado por Rui Torres, na medida em que sua obra adota o mar como grande metáfora e também como meio de dicção. Tal estrutura fluida, com palavras e versos que soçobram e vêm à tona, em movimentos de cadência regular, funciona como o oceano a que convencionalmente se associa o cyberespaço.

Nesta interpretação, optamos por manter a metáfora náutica e colocamo-nos como o leitor que, diante da algaravia de sinais que Mar de Sophia lhe oferece, tem que traçar uma rota de leitura, para prosseguir com sua navegação em meio aos destroços de outros textos, seja na forma de palavras, como em "Retrato de uma princesa", seja na forma de versos, como em "Poema \#2". Para tanto, estabelecemos aqui pontes com outros poemas de Sophia e com Alice no País das Maravilhas, além de análises comparativas entre segmentos do Mar de Sophia, em navegação ziguezagueante a fim de singrar este mar discursivo.

Por vezes, tal leitura exigiu-nos que se transpusesse para o eixo do sintagma o procedimento de frouxas associações por similaridade caras ao eixo do paradigma, conforme Jakobson (1992) já anunciara quando da análise das especificidades semióticas da poesia. Sendo Mar de Sophia uma obra que explora ao limite da lira esse jogo entre sintagma (texto na tela) e paradigma (elementos no banco de dados), pareceu-nos ser esse o instrumento de navegação mais acertado para esta travessia, como astrolábio a que pudéssemos confiar nosso destino exegético.

\section{Referências}

ANDRESEN, Sophia de Mello Breyner. Obra poética I, II e III. Lisboa: Caminho, 1991.

Dual. Ed. definitiva. Lisboa: Caminho, 2004. O nome das coisas. Lisboa: Moraes editores, 1977.

BARBOSA, Pedro. O computador como máquina semiótica. Revista de Comunicação \& Linguagens. Lisboa, Universidade Nova de Lisboa, n. 29, abr/2001. Disponível em <www. pedrobarbosa.net>. Acesso: jul. 2016.

BONACHO, Fernanda do Rosário Farinha. A leitura em ambiente digital: transliteracias da comunicação. 2003. 215 f. Tese (Doutorado em Ciências da Comunicação) - Faculdade de Ciências Humanas e Sociais da Universidade Nova de Lisboa. 2003.

GENETTE, Gérard. Palimpsestos: a literatura de segunda mão. Trad. Cibele Braga et al. Belo horizonte: Edições Viva Voz, 2010.

JAKOBSON, Roman. Linguística e comunicação. Tradução J. Blikstein e José Paulo Paes. São Paulo: Cultrix, 1992.

PESSOA, Fernando. Mensagem - Poemas esotéricos. Edição crítica; coordenação de José Augusto Seabra. Madrid; Paris; México; Buenos Aires; São Paulo; Rio de Janeiro; Lima: ALLCA XX (Edições Unesco), 1996.

PO.EX. Arquivo Digital da PO.EX. 2016. Disponível em $<$ http://po-ex.net>. Acesso em 15 ago 2016.

SANTAELLA, Lúcia. Navegar no ciberespaço: o perfil cognitivo do leitor imersivo. São Paulo: Paulus, 2004.

TORRES, Rui. Mar de Sophia. 2004. Disponível em <http:/ telepoesis.net/mardesophia>. Acesso em 20 ago 2016.

Recebido: 07 de setembro de 2016 Aprovado: 29 de junho de 2017 Contato: viniciuscarpe@gmail.com 